\begin{tabular}{|c|c|c|}
\hline decartesian 9 & Jumal Matematika dan Aplikasi & \\
\hline & de Oanterian & \\
\hline$=$ & 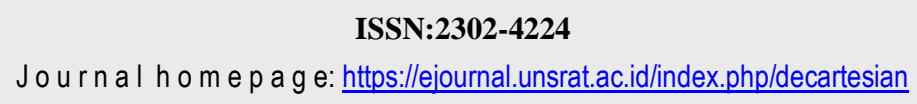 & $\mathbf{a N}$ \\
\hline
\end{tabular}

\title{
Analisis Survival Dalam Menentukan Faktor-faktor Yang Mempengaruhi Lama Studi Mahasiswa Matematika Di Jurusan Matematika FMIPA Universitas Sam Ratulangi Manado
}

\author{
Noivia Cyta Hari' ${ }^{1}$ Hanny Komalig ${ }^{*}$, Yohanes A.R Langi ${ }^{1}$ \\ ${ }^{1}$ Jurusan Matematika-Fakultas Matematika dan Ilmu Pengetahuan Alam-Universitas Sam Ratulangi Manado,Indonesia \\ *Corresponding author: hanoyo7@yahoo.com
}

\begin{abstract}
A B S T RA K
Lama studi merupakan waktu yang dibutuhkan seorang mahasiswa untuk menyelesaikan pendidikan. Terkait dengan proses belajar mahasiswa, ternyata banyak hal yang dapat memengaruhi mahasiswa untuk dapat bertahan sehingga mahasiswa dapat melanjutkan ke semester berikutnya. Faktor-faktor yang mempengaruhi lama studi mahasiswa bisa berasal dari faktor internal dan faktor eksternal. Penelitian ini dilakukan selama 10 bulan sejak bulan Agustus 2017 sampai bulan Juni 2018.Tujuan dari penelitian ini adalah menentukan faktor faktor yang berpengaruh signifikan terhadap lama studi mahasiswa Jurusan Matematika FMIPA Unsrat dengan menggunakan Regresi Cox Proportional Hazard . Dari hasil analisis pada lama studi mahasiswa jurusan Matematika FMIPA Unsrat dapat diperoleh kesimpulan bahwa variabel Jenis Kelamin (X1) dan variabel Asal Daerah (X2) tidakberpengaruh secara signifikan terhadap lama studi mahasiswa S-1 jurusan Matematika FMIPA Unsrat dan untuk variabel IPK $\left(\mathrm{X}_{3}\right)$ berpengaruh terhadap lama studi mahasiswa. Model regresi Cox Proportional Hazard dari faktor-faktor yang mempengaruhi lama studi mahasiswa jurusan Matematika FMIPA Unsrat diperoleh sebagai berikut :
\end{abstract}

$h(t, X)=h_{0}(t) \cdot\left(\exp \left(0.426 X_{1}+0.89 X_{2}-0.602 X_{3}\right)\right)$.

\author{
INFO ARTIKEL \\ Diterima : 6 September 2018 \\ Diterima setelah revisi $: 14$ September 2018 \\ Tersedia online $\quad$ : 30 September 2018
}

\section{Kata Kunci:}

Analisis Survival

Regresi Cox

Metode Kaplan-Meier

\section{PENDAHULUAN}

Lama studi merupakan waktu yang dibutuhkan seorang mahasiswa untuk menyelesaikan pendidikan sesuai dengan jenjang masing-masing, biasanya untuk jenjang Strata Satu (S1) adalah 4 tahun. Terkait dengan proses belajar mahasiswa, ternyata banyak hal yang dapat memengaruhi mahasiswa untuk dapat bertahan sehingga mahasiswa dapat melanjutkan ke semester berikutnya. Faktor-faktor yang mempengaruhi lama studi mahasiswa bisa berasal dari faktor internal dan faktor eksternal.

Analisis ketahanan hidup menggambarkan analisis data waktu tahan hidup dari awal waktu penelitian sampai kejadian tertentu terjadi [1]. Regresi Cox Proportional Hazards merupakan metode regresi dalam analisis ketahanan hidup yang digunakan untuk mengetahui hubungan antara variabel dependen dengan variabel independen.

Analisis survival dalam memodelkan daya tahan mahasiswa telah digunakan pada penelitian sebelumnya. Faktor yang mempengaruhi lama studi mahasiswa yaitu nilai IPK mahasiswa tersebut [2]. Ada juga faktor yang mempengaruhi lama studi mahasiswa yaitu jenis kelamin, IPK dan fakultas [3]. Dengan mahasiswa laki-laki memiliki peluang lebih cepat Drop Out dari pada mahasiswa perempuan.

Metode Regresi Survival adalah metode regresi yang digunakan untuk melihat faktor - faktor yang menyebabkan terjadinya suatu peristiwa atau kejadian dengan variabel responnya adalah waktu ketahanan. Salah satu regresi survival yang sering digunakan adalah Regresi Cox Proportional Hazard yang dimaksud dalam penelitian ini adalah kemampuan mahasiswa dalam menyelesaikan studinya. Regresi Cox Proportional Hazard juga merupakan pendekatan model matematika yang digunakan untuk mengestimasi kurva survival ketika mempertimbangkan beberapa variabel.

\section{ANALISIS SURVIVAL}

Secara umum analisis survival dideskripsikan sebagai kumpulan prosedur statistik untuk menganalisis data yang variabel akhirnya adalah waktu hingga muncul kejadian [4]. Analisis survival 
merupakan alat statistik dengan tujuan utamanya adalah menganalisis data yang selalu positif dalam skala pengukuran dengan jarak interval data awal dan akhir [5].

\subsection{Jenis - Jenis Pensensoran}

Pensensoran adalah salah satu langkah yang harus dilakukan untuk mengatasi ketidaklengkapan suatu data pengamatan.

Dalam analisis survival terdapat 3 tipe penyensoran yaitu [6]:

\subsubsection{Sensor Kanan ( Right Censoring)}

Sensor yang terjadi dikarenakan objek pengamatan belum mengalami kejadian hingga akhir periode pengamatan, sedangkan waktu awal dari objek pengamatan dapat diamati secara penuh. Misalkan suatu individu diamati selama empat tahun dari awal pengamatan, kemudian pada tahun ketiga individu tersebut pindah ke negara lain dan tidak dapat diamati lagi (lost to follow up). Individu ini memiliki waktu survival dalam penelitian setidaknya dua tahun, sehingga waktu pengamatan individu tersebut dikatakan tersensor kanan.

\subsubsection{Sensor Kiri (Left Censoring)}

Sensor yang terjadi dikarenakan waktu awal dari subjek pengamatan tidak dapat teramati pada awal pengamatan, sementara kegagalan dapat diamati secara penuh sebelum penelitian berakhir. Sebagai contoh, peneliti mengamati pasien penyakit kanker, peneliti dapat mencatat kejadian tepatnya seseorang tersebut positif kanker di tes pertamanya, namun peneliti tidak memiliki catatan tentang waktu tepatnya seseorang tersebut mulai berpenyakit kanker, dengan demikian pasien kanker tersebut tersensor kiri yaitu ketika mengalami kejadian pertama dengan hasil positif kanker.

\subsubsection{Sensor Interval (Interval Censoring)}

Sensor interval adalah sensor yang waktu survivalnya berada dalam suatu selang tertentu, Sebagai contoh jika catatan medis menunjukkan bahwa pada usia 45 tahun pasien kanker dalam contoh di atas kondisinya sehat dan belum berpenyakit kanker, kemudian pasien melakukan tes pertama saat berumur 50 tahun dan terdiagnosis terkena penyakit kanker, dengan demikian usia saat didiagnosis positif kanker adalah antara 45 dan 50 tahun.

\subsection{Fungsi -Fungsi Dalam Analisis Survival 2.2.1. Fungsi Kepekatan Peluang ( Probability Density Function)}

Fungsi kepekatan peluang dari waktu daya tahan $T$ didefenisikan sebagai peluang dari suatu individu yang gagal pada selang waktu $t$ sampai $\Delta t$ yang di notasikan dengan $f(t)$. Fungsi ini dirumuskan sebagai berikut :

$$
\begin{aligned}
f(t) & =\lim _{\Delta t \rightarrow 0} \frac{P((\text { individu gagal dalam interval } t) t+\Delta t)}{\Delta t} \\
f(t) & =\lim _{\Delta t \rightarrow 0} \frac{P(t \leq T<(t+\Delta t))}{\Delta t} \\
& =\lim _{\Delta t \rightarrow 0} \frac{F(t+\Delta t)-F(t)}{\Delta t}
\end{aligned}
$$$$
T \text { merupakan variabel acak non negatif dalam }
$$
interval $[0, \infty), F(t)$ merupakan fungsi distribusi kumulatif dari $T$. Sehingga fungsi ini dapat didefenisikan sebagai peluang suatu individu mengalami event sampai dengan waktu $t$ :

$F(t)=P(T \leq t)$

$F(t)=\int_{0}^{t} f(x) d x$

Dari persamaan (2) diatas dengan melakukan penurunan terhadap $d t$ pada kedua sisi diperoleh :

$F^{\prime}(t)=D_{t}\left(\int_{0}^{t} f(x) d x\right)=f(t)$

\subsubsection{Fungsi Survival (Survival Function)}

Fungsi Survival menjelaskan ukuran waktu terjadinya suatu kejadian. Fungsi daya tahan ini dapat didefinisikan sebagai peluang mahasiswa bertahan dalam melanjutkan studi selama kurun waktu $t$ yang dinyatakan dalam bentuk:

$\mathrm{S}(\mathrm{t})=\mathrm{P}($ Suatu individu bertahan $>\mathrm{t})$

$=P(T \geq t)=\int_{t}^{\infty} f(u) d u$

\subsubsection{Fungsi Hazard (Hazard Function)}

Fungsi Hazard $h(t)$ dari waktu daya tahan $T$ disebut sebagai laju kegagalan bersyarat (conditional failure rate), yang didefenisikan sebagai peluang terjadinya kegagalan bahwa individu sudah bertahan hidup selama waktu $t$. Fungsi Hazard dinyatakan seabgai berikut :

$$
\begin{aligned}
h(t) & =\lim _{\Delta \mathrm{t} \rightarrow 0} \frac{P(\text { individu gagal dalam interval }(\mathrm{t}, \mathrm{t}+\Delta \mathrm{t})}{\Delta \mathrm{t}} \\
\mathrm{h}(\mathrm{t}) & =\lim _{\Delta \mathrm{t} \rightarrow 0} \frac{\mathrm{P}\{\mathrm{t} \leq \mathrm{T}<\mathrm{t}+\Delta \mathrm{t}) \mid \mathrm{T}>\mathrm{t}\}}{\Delta \mathrm{t}} \\
& =\frac{\mathrm{f}(\mathrm{t})}{\mathrm{S}(\mathrm{t})}
\end{aligned}
$$

Hubungan $S(t)$ dan $h(t)$ adalah jika nilai $S(t)$

naik maka nilai $h(t)$ turun, begitu juga sebaliknya jika nilai $S(t)$ turun maka nilai $h(t)$ naik.

\subsection{Model Regresi Cox Proportional Hazard}

Model Regresi Cox diperkenalkan oleh D.R Cox pada tahun 1972 dan pertama kali diterapkan pada data survival.

Regresi Cox Proportional Hazard atau lebih dikenal sebagai model Regresi Cox digunakan untuk mengetahui hubungan antara variabel dependen dengan variabel independen, dimana data yang digunakan pada Regresi Cox Proportional Hazardsberupa data ,waktu tahan hidup dari suatu individu. Menurut Collet (2004), model Regresi Cox Proportional Hazardsadalah sebagai berikut:

$h(t, X)=h_{0}(t) \cdot\left(\exp \left(-\left(\beta_{1} x_{1}+\beta_{2} x_{2}+\ldots+\beta_{p} x_{p}\right)\right.\right.$

Keterangan :

$\mathrm{h}(\mathrm{t}, \mathrm{X})=$ Resiko mahasiswa gagal pada waktu $t$ dengankarakteristik $X$

$\mathrm{h}_{0}(\mathrm{t})=$ Fungsi hazard dasar atau fungsi hazard pada saat $\mathrm{t}=\mathrm{O}$ tidak bergantung pada karakteristik

$\mathrm{X}=$ merupakan variabel prediktor atau penjelas

$\mathrm{P}=\left(\mathrm{p}_{1}, \mathrm{p}_{2}, \ldots \mathrm{p}_{\mathrm{n}}\right)$ jumlah dari variabel penjelas $X$

$\mathrm{B}=\left(\beta_{1}, \beta_{2}, \ldots \beta_{\mathrm{p}}\right)$ merupakan vektor koefisien regresi atau vektor parameter

Pemodelan fungsi hazard pada analisis Regresi Cox adalah sebagai berikut :

$h(t)=h_{0}(t) \exp (y)$

\subsection{Estimasi Kaplan-Meier}

Cara yang digunakan untuk menggambarkan survival dari sampel acak $t_{1}, \ldots, t_{n}$ yaitu dengan menggambarkan grafik fungsi survival atau fungsi distribusi empiris dengan cara estimasi Kaplan-Meier. Selain itu memberikan juga estimasi distribusi secara nonparametrik. 
Diberikan $\left(\mathrm{t}_{\mathrm{i}}^{\prime}, \delta_{\mathrm{i}}\right), \mathrm{i}=1, \ldots, \mathrm{n}$ yang menyatakan sampel random tersensor, dengan $\delta_{\mathrm{i}}=1$ merupakan data terobservasi dan $\delta_{\mathrm{i}}=0$ merupakan data tersensor. Misalkan terdapat $\mathrm{k}(\mathrm{k} \leq \mathrm{n})$ dengan waktu yang berbeda $t_{1}<t_{2}<\cdots<t_{k}$, yang menyatakan banyaknya data yang terobservasi . kemungkinan terjadinya satu atau lebih event yang terobservasi dinotasikan sebagai $\mathrm{d}_{\mathrm{j}}=\sum \mathrm{I}\left(\mathrm{t}_{\mathrm{i}}^{\prime}=\mathrm{t}_{\mathrm{j}}, \delta_{\mathrm{i}}=1\right)$ atau menyatakan banyaknya eventterobservasi pada saat $t_{j}$. Estimasi dari $\widehat{S}(\mathrm{t})$ dapat di definisikan sebagai berikut :

$\widehat{S}(t)=\prod_{t_{j}<t} \frac{n_{j}-d_{j}}{n_{j}}$

dengan $n_{j}=\sum I\left(t_{i}^{\prime} \geq t_{j}\right)$ merupakan banyaknya individu yang beresiko pada saat $t_{j}$ dengan kata lain banyaknya individu yang belum mengalami kejadian atau event dan tidak tersensor sebelum pada saat $t_{j}$ [7].

\subsection{Pengujian Asumsi Proportional Hazard}

Cara untuk memeriksa asumsi Proportional Hazard secara visual dengan melihat grafis dari plot $\log \{-\log [\mathrm{S}(\mathrm{t}, \mathrm{x})]\}$ terhadap waktu survival.

Setiap plot antara kategori dalam satu variabel penjelas terlihat sejajar atau tidak saling bersilangan maka asumsi proportional hazard terpenuhi [8].

\section{METODOLOGI PENELITIAN}

\subsection{Waktu dan Tempat Penelitian}

Penelitian ini dilakukan pada bulan Agustus 2017 sampai bulan Juni 2018 di Fakultas MIPA Universitas Sam Ratulangi Manado.

\subsection{Sumber Data}

Data yang digunakan dalam penelitian ini berasal dari data sekunder. Data sekunder berupa data yang di ambil di Pusat Teknologi Informasi (PTI) Universitas Sama Ratulangi Manado.

\subsection{Objek Penelitian}

Objek Penelitian yaitu Mahasiswa Matematika Fakultas MIPA Universitas Sam Ratulangi Manado angkatan $2009-2013$.

\subsection{Variabel Penelitian}

Variabel yang diduga mempengaruhi masa studi mahasiswa FMIPA Unsrat antara lain:

1. Jenis Kelamin $\left(\mathrm{X}_{1}\right)$

1. Laki-laki

2. Perempuan

2. Asal Daerah Mahasiswa $\left(X_{2}\right)$

1. Manado

2. Luar Manado

3. IPK Semester $\left(X_{3}\right)$

1. $\quad$ IPK $\leq 3.50$

2. $\quad \mathrm{IPK}>3.50$

\subsection{Diagram Alur Penelitian}

Menentukan faktor-faktor yang mempengaruhi- lama masa studi mahasiswa jurusan matematika FMIPA Unsrat

Melakukan pengolahan data dengan melakukan estimasi survival dari data lama studi mahasiswa S-1 matematika FMIPA Unsrat dengan metode Kaplan-Meier

$$
\downarrow
$$

Melakukan pemeriksaan asumsi Proportional Hazard dengan menggunakan plot $\ln \{\hat{S}[t]\}$ terhadap waktu $(t)$

\section{$\downarrow$}

Melakukan uji statistik dengan menggunakan analisis $C o x$ Proportional Hazard

Gambar 1. Diagram Alir Penelitian

\section{HASIL DAN PEMBAHASAN}

\subsection{Gambaran Umum Data}

\subsubsection{Variabel X1 (Jenis Kelamin)}

Jenis kelamin Mahasiswa Jurusan Matematika FMIPA Unsrat angkatan 2009-2013 dikategorikan menjadi 2 kategori yaitu laki-laki dan perempuan. Sampel yang di ambil dari Mahasiswa Jurusan Matematika Universitas Sam Ratulangi angkatan 2009-2013 berjumlah 64 mahasiswa yang berjenis kelamin laki-laki berjumlah 19 orang dan perempuan berjumlah 45 orang. Distribusi frekuensi jenis kelamin Mahasiswa Jurusan Matematika angkatan 2009-2013 disajikan pada gambar 2 .

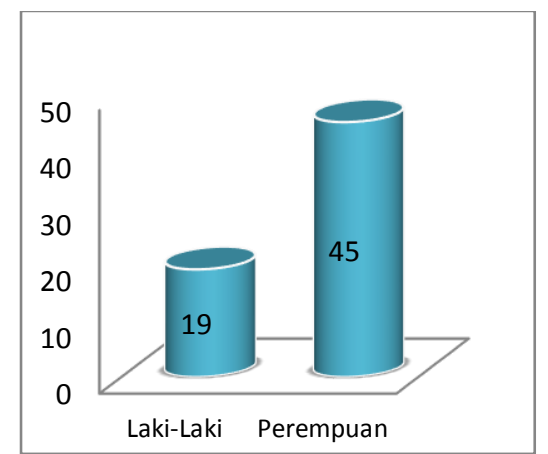

Gambar 2. Distribusi Frekuensi Jenis Kelamin Mahasiswa Jurusan Matematika Angkatan 2009-2013

\subsubsection{Variabel $X_{2}$ (Asal Daerah)}

Asal daerah Mahasiswa Jurusan MatematikaFMIPA Unsrat tahun 2009-2013 dikategorikan menjadi 2 yaitu Manado dan Luar Manado. Mahasiswa dari luar manado berasal dari Kota Bitung, Minahasa, Kabupaten Sitaro, Kabupaten Sangihe, Kabupaten Talaud dan diluar Provinsi Sulawesi Utara. . Dari 64 mahasiswa Jurusan Matematika FMIPA Unsrat angkatan 2009 - 2013 diperoleh data mahasiswa dari Manado 40 orang dan dari luar Manado 24 orang. Distribusi frekuensi Asal Daerah Mahasiswa Jurusan Matematika angkatan 2009-2013 disajikan pada gambar 3 . 


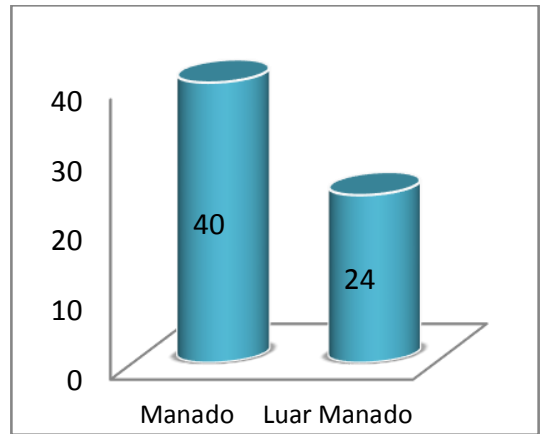

Gambar 3. Distribusi Frekuensi Asal Daerah Mahasiswa Jurusan Matematika Angkatan 2009-2013

\subsubsection{Variabel $X_{3}$ (IPK)}

Indeks Prestasi Kumulatif (IPK) Mahasiswa Jurusan Matematika FMIPA Unsrat angkatan 2009 2013 dikategorikan menjadi 2 kategori yaitu IPK > 3.50 dan IPK $\leq$ 3.50. Dari 64 Mahasiswa Jurusan Matematika angkatan 2009 sampai 2013 diperoleh data mahasiswa dengan IPK $>3.50$ berjumlah 26 orang, dan IPK $\leq 3.50$ berjumlah 38 orang. Distribusi frekuensi IPK Mahasiswa Jurusan Matematika angkatan 2009-2013 disajikan pada gambar 4 .

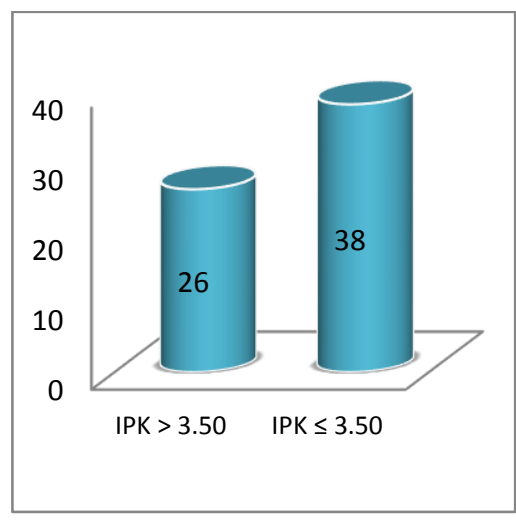

Gambar 4. Distribusi Frekuensi Indeks Prestasi Komulatif Mahasiswa Jurusan Matematika Angkatan 2009-2013

\subsection{Analisis Distribusi Data}

Tabel 1. Sampel Analisis Distribusi DataMahasiswa Matematika Angkatan 2009 -2013

\begin{tabular}{|l|l|c|c|}
\cline { 3 - 4 } \multicolumn{2}{c|}{} & Frekuensi & Presentasi \\
\hline Kejadian & Terobservasi & 58 & $90.62 \%$ \\
& Tersensor & 6 & $9.38 \%$ \\
\hline \multicolumn{2}{|c|}{ Total } & 64 & $100 \%$ \\
\hline
\end{tabular}

Dari tabel 1, dapat dilihat bahwa banyaknya mahasiswa yang terobservasi atau banyaknya mahasiswa matematika angkatan 2009 - 2013 yang lulus (yudisium) yaitu 58 mahasiswa atau $90.62 \%$. Sedangkan untuk mahasiswa yang tersensor atau banyaknya mahasiswa yang masih mengikuti studi sampai saat ini adalah 6 mahasiswa atau $9.38 \%$.

Dari tabel 2 dapat dilihat bahwa dari 19 mahasiswa laki-laki terdapat 18 mahasiswa yang terobservasi dan 1 mahasiswa tersensor. Sedangkan dari 45 mahasiswa perempuan terdapat 40 mahasiswa terobservasi dan 5 mahasiswa tersensor
Tabel 2. Analisis Distribusi Data Mahasiswa Matematika Angkatan 2009 - 2013 untuk Faktor Jenis Kelamin

\begin{tabular}{|c|c|c|c|c|}
\hline \multirow{2}{*}{$\begin{array}{c}\text { Jenis } \\
\text { Kelamin }\end{array}$} & $\begin{array}{c}\text { Total } \\
\mathrm{N}\end{array}$ & \multirow{2}{*}{$\begin{array}{c}\mathrm{N} \text { of } \\
\text { Events }\end{array}$} & \multicolumn{2}{|c|}{ Sensor } \\
\cline { 4 - 5 } & & & $\mathrm{N}$ & Persen \\
\hline $\mathrm{O}$ & 45 & 40 & 5 & $11.1 \%$ \\
\hline 1 & 19 & 18 & 1 & $5.3 \%$ \\
\hline & 64 & 58 & 6 & $9.4 \%$ \\
\hline
\end{tabular}

Tabel 3. Analisis Distribusi Data Mahasiswa Matematika Angkatan 2009 - 2013 untuk Faktor Asal Daerah

\begin{tabular}{|c|c|c|c|c|}
\hline $\begin{array}{c}\text { Asal } \\
\text { Daera } \\
\text { h }\end{array}$ & $\begin{array}{c}\text { Total } \\
\mathrm{N}\end{array}$ & $\begin{array}{c}\text { N of } \\
\text { Events }\end{array}$ & \multicolumn{2}{|c|}{ Sensor } \\
\cline { 4 - 5 } & & & $\mathrm{N}$ & Persen \\
\hline $\mathrm{O}$ & 24 & 23 & 1 & $4.2 \%$ \\
\hline 1 & 40 & 35 & 5 & $12.5 \%$ \\
\hline & 64 & 58 & 6 & $9.4 \%$ \\
\hline
\end{tabular}

Dari tabel 3 dapat kita lihat bahwa mahasiswa yang asal Manado berjumlah 40 mahasiswa, terdapat 35 mahasiswa terobservasi dan 1 mahasiswa tersensor. Sedangkan untuk mahasiswa yang dari Luar Manado berjumlah 24 mahasiswa, 35 mahasiswa terobservasi dan 5 mahasiswa tersensor.

Tabel 4. Analisis Distribusi Data Mahasiswa Matematika Angkatan 2009 - 2013 untuk Faktor IPK

\begin{tabular}{|c|c|c|c|c|}
\hline IPK & Total & \multirow{2}{*}{$\begin{array}{c}\text { N of } \\
\text { Events }\end{array}$} & \multicolumn{2}{|c|}{ Sensor } \\
\cline { 4 - 5 } & & & $\mathrm{N}$ & Persen \\
\hline 0 & 38 & 32 & 6 & $15.8 \%$ \\
\hline 1 & 26 & 26 & 0 & $0.0 \%$ \\
\hline & 64 & 58 & 6 & $9.4 \%$ \\
\hline
\end{tabular}

Dari tabel 4 dapat dilihat bahwa kategori IPK > 3.50 dari 26 mahasiswa terdapat 26 mahasiswa terobservasi dan tidak ada mahasiswa yang tersensor. Sedangkan untuk kategori IPK $\leq 3.50$ dari 38 mahasiswa terdapat 32 mahasiswa terobservasi dan 6 mahasiswa tersensor.

\subsection{Uji Asumsi Proportional Hazard}

Pengujian asumsi Proportional Hazard dilakukan untuk mengidentifikasi apakah setiap variabel yang diduga berpengaruh memenuhi asumsi tersebut. Apabila garis Survival pada kurva Kaplan-Meier tidak saling berpotongan maka asumsi Proportional Hazard dinyatakan terpenuhi.

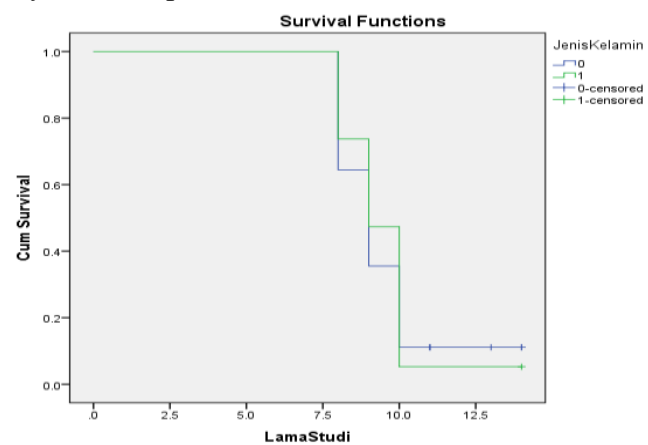

Gambar 5. Grafik Survival untuk faktor Jenis Kelamin $\left(X_{1}\right)$ 
Berdasarkan Gambar 5 dapat dilihat bahwa grafik Survival untuk variabel Jenis Kelamin $\left(X_{1}\right)$ tidak saling berpotongan sehingga dapat ditarik kesimpulan bahwa variabel $X_{1}$ memenuhi asumsi.



Gambar 6.Grafik Survival untuk faktor Asal Daerah

Berdasarkan Gambar 6 dapat dilihat bahwa grafik Survival untuk variabel Asal Daerah $\left(X_{2}\right)$ tidak saling berpotongan sehingga dapat ditarik kesimpulan bahwa variabel $X_{2}$ memenuhi asumsi.

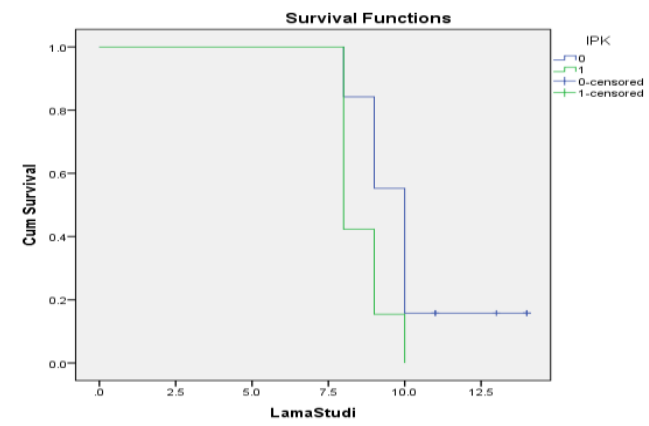

Gambar 7. Grafik Survival untuk faktor IPK (Indeks Prestasi Kumulatif)

Dari Gambar 7 dapat dilihat bahwa grafik Survival tidak bersilangan atau berpotongan maka variabel $X_{3}$ memenuhi asumsi proportional hazard tetapi kesimpulannya dapat diambil setelah dilakukan uji parsial.

\subsection{Uji Signifikan Parameter}

\subsubsection{Uji Simultan Parameter}

Uji simultan ini dilakukan untuk mengetahui signifikan dari model secara serentak atau overall. Statistik uji yang digunakan uji $\mathrm{G}$ dengan hipotesis sebagai berikut :

$\mathrm{H}_{0}: \beta_{\mathrm{i}}=0$

(tidak ada pengaruh)

$\mathrm{H}_{1}: \beta_{\mathrm{i}} \neq 0, \mathrm{i}=1,2, \ldots, \mathrm{p}$ (ada pengaruh)

Tolak $\mathrm{H}_{0}$ jika $\mathrm{p}$-value $<\propto=0,05$ atau $5 \%$

Tabel 5. Koefisien Uji Model Omnibus

\begin{tabular}{|c|c|c|c|}
\hline $\begin{array}{c}-2 \text { Log } \\
\text { Likelihood }\end{array}$ & \multicolumn{3}{|c|}{ Overall (score) } \\
\cline { 2 - 4 } & Chi-square & df & Sig. \\
\hline 422.051 & 11.036 & 3 & .012 \\
\hline
\end{tabular}

Hasil yang dapat kita lihat pada Tabel 20 diperoleh nilai signifikan sebesar 0,012 dimana signifikansi lebih kecil dari nilai $\alpha=0,05$. Maka kesimpulannya $H_{0}$ ditolak yang berarti ada variabel bebas yang berpengaruh terhadap variabel terikat.

\subsubsection{Uji Parsial}

Uji parsial ini dilakukan untuk menguji koefisien

( $\beta$ ) dan uji ini biasanya menggunakan statistic uji
Wald. Pengujian ini berfungsi untuk melihat variabel independent atau setiap kovariat berpengaruh signifikan atau tidak.

Hipotesis untuk pengujian ini adalah sebagai berikut : $H_{0}$ : Variabel independent tidak berpengaruh signifikan terhadap model

$H_{1}$ : Variabel independent berpengaruh signifikan terhadap model

Tabel 6. Variabel dalam Persamaan

\begin{tabular}{|c|c|c|c|c|c|c|}
\hline & B & SE & Wald & df & Sig. & Exp(B) \\
\hline $\begin{array}{c}\text { Jenis } \\
\text { Kelamin }\end{array}$ & -.426 & .288 & 2.186 & 1 & .139 & .653 \\
\hline $\begin{array}{c}\text { Asal } \\
\text { Daerah }\end{array}$ & -.089 & .274 & .105 & 1 & .746 & .915 \\
\hline IPK & .602 & .273 & 4.846 & 1 & .028 & 1.825 \\
\hline
\end{tabular}

Dengan nilai $\alpha=0,05$ dan $\mathrm{df}=1$ pada tabel chisquare maka diperoleh nilai chi-square tabel $=3,841$. Dari tabel diatas, nilai uji statistic wald pada Variabel Jenis Kelamin dan Asal daerah lebih kecil dari nilai chi-square yang berarti tidak ada pengaruh variabel independent secara individu sedangkan untuk nilai wald pada Variabel IPK lebih besar dari nilai chisquare yang berarti Variabel IPK berpengaruh.

\subsubsection{Model Regresi CoxProportional Hazard}

Berdasarkan analisis data yang telah dilakukan dengan maka diperoleh nilai koefisien variabel sebagai berikut :

Tabel 7. Nilai Koefisien Variabel

\begin{tabular}{|c|c|}
\hline Variabel & B \\
\hline Jenis Kelamin & -0.426 \\
\hline Asal Daerah & -0.089 \\
\hline IPK & 0.602 \\
\hline
\end{tabular}

Berdasarkan Tabel 22 di atas maka diperoleh nilai koefisien dari masing - masing variabel adalah sebagai berikut :

$\beta_{1}=-0.426$

$\beta_{2}=-0.089$

$\beta_{3}=0.60$

Setelah nilai $\beta$ dari setiap variabel di dapatkan kemudian akan disubstitusikan ke dalam model umum Regresi Cox :

$h(t, X)=h_{0}(t) \cdot\left(\exp -\left(\beta_{1} x_{1}+\beta_{2} x_{2}+\ldots+\beta_{p} x_{p}\right)\right)$

$\mathrm{h}(\mathrm{t}, \mathrm{X})=\mathrm{h}_{0}(\mathrm{t}) \cdot\left(\exp \left(0.426 \mathrm{x}_{1}+0.89 \mathrm{x}_{2}-0.602 \mathrm{x}_{3}\right)\right)$

Dari model regresi di atas dapat di intrepretasikan bahwa nilai koefisien regresi variabel $X_{1}=0.426$, dan $X_{2}=0.089$ yang berarti tidak berpengaruh terhadap lama studi mahasiswa Jurusan Matematika Fakultas MIPA Unsrat yang dapat dilihat pada tabel 21 dimana nilai koefisien variabel $X_{1}$ dan $X_{2}$ adalah sebesar 0.139 dan 0.746 yang mana lebih besar dari nilai taraf signifikan yaitu 0.05. Sedangkan untuk nilai koefisien variabel $X_{3}$ adalah sebesar -0.602 yang mana lebih kecil dari nilai taraf signfikan yaitu 0.05 yang berarti memiliki pengaruh terhadap lama studi mahasiswa Jurusan Matematika Fakultas MIPA.

Jadi, dapat disimpulkan bahwa variabel Jenis Kelamin $\left(X_{1}\right)$, variabel Asal Daerah $\left(X_{2}\right)$ tidak berpengaruh terhadap lama studi mahasiswa di Jurusan Matematika Fakultas MIPA dan untuk variabel IPK $\left(X_{3}\right)$ berpengaruh terhadap lama studi mahasiswa di Jurusan Matematika Fakultas MIPA Unsrat. 


\section{KESIMPULAN}

Dari hasil pembahasan untuk lama studi mahasiswa jurusan Matematika FMIPA Unsrat dapat disimpulkan bahwa variabel Jenis Kelamin $\left(X_{1}\right)$ dan variabel Asal Daerah $\left(X_{2}\right)$ tidakberpengaruh secara signifikan terhadap lama studi mahasiswa S-1 jurusan Matematika FMIPA Unsrat dan untuk variabel IPK $\left(X_{3}\right)$ berpengaruh terhadap lama studi mahasiswa. Model regresi Cox Proportional Hazard dari faktorfaktor yang mempengaruhi lama studi mahasiswa jurusan Matematika FMIPA Unsrat diperoleh sebagai berikut :

$$
h(t, X)=h_{0}(t) .\left(\exp \left(0.426 x_{1}+0.89 x_{2}-0.602 x_{3}\right)\right)
$$

\section{DAFTAR PUSTAKA}

[1] Collet, D. 2004. Modelling Survival Data in Medical Research, London: CRC Press.

[2] As'ari A.W. 2012. Pendekatan Regresi Cox Proporsional Hazard Dalam Penentuan FaktorFaktor Yang Berpengaruh Terhadap Lama Studi Mahasiswa S-1 Matematika Di Universitas Airlangga [Skripsi]. Program Studi S-1 Matematika Departemen Matematika Fakultas Sains Dan Teknologi Universitas Airlangga. Surabaya

[3] Imran F. 2013. Identifikasi Faktor-Faktor Yang Berhubungan Dengan Mahasiswa Putus Kuliah Di IPB Angkatan 2008 Menggunakan analisis survival. Departemen Statistika FMIPA IPB. Bogor

[4] Kleinbaum DG, 1996. Survival analysis : a self learning text. Springer-Verlag. New York.

[5] Lee, E. T. 1992. Statsitical Methods for Survival Data Analysis.John Wiley \& Sons, Inc. Canada.

[6] Collet, D., 1994. Modelling Survival Data in Medical Research, London: Chapman \& Hall

[7] Lawless,J.F.1982. Statistical Model and Method for lifetime Data. New York

[8] Kleinbaum DG., \& Klein Mitchel. 2005. Survival Analysis : A Self Learning Text ( $\left.2^{\text {nd }}\right)$.Springer. New York
Noivia Cyta Hari (noiviacyta_hari@yahoo.com)

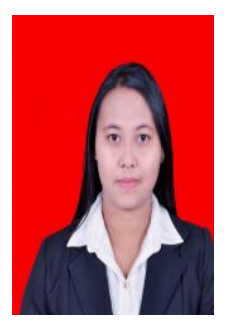

Lahir di Lumbo, Kecamatan Tagulandang Utara Kabupaten Siau Tagulandang Biaro.

Menempuh pendidikan tinggi Jurusan Matematika, FMIPA, Universitas Sam Ratulangi Manado. Tahun 2018 adalah tahun terakhir ia menempuh studi. Makalah ini merupakan hasil penelitian skripsinya yang dipublikasikan.

Hanny A.H. Komalig (hanoyo7@yahoo.com )



Pada tahun 1990, memperoleh gelar Insinyur di Fakultas Pertanian Universias Sam Ratulangi Manado. Kemudian ia mengikuti Basic Science Bridging Program Bidang Matematika di Institut teknologi Bandung tahun 1992 selama 2 tahun. Selanjutnya memperoleh gelar Magister Sains bidang Statistika di Institut Pertanian Bogor tahun 1998. Dan pada tahun 2008 memperoleh gelar Doktor di Universita Air Langga Surabaya untuk Bidang Matematika Modeling. Menjadi Dosen di Departemen Matematika, FMIPA, Universitas Sam Ratulangi pada tahun 2000 sampai sekarang. Bidang Keahlian yang di tekuni yaitu diantaranya : Statistika Multivariat Non Linier dan Reduksi Dimensi

Yohanes A.R. Langi ( yarlangi@unsrat.ac.id )

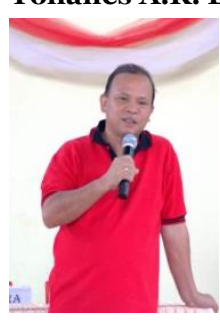

Pada tahun 1994, memperoleh gelar Sarjana di Departemen Matematika, FMIPA, Universitas Kristen Tomohon. Gelar Magister bidang Biometrika, Institut Pertanian Bogor, pada than 2007. Menjadi Dosen di Departemen Matematika, FMIPA, Unviersitas Sam Ratulangi Manadosejak tahun 2005 sampai sekarang dengan bidang keahlian yang ditekuni yaitu diantaranya : Proses Stokastik, Perancangan Percobaan, dan Biometrika 